випадки прийняття юридично значимих рішень, повинні бути сформульовані на рівні правового регулювання.

\title{
Література:
}

1. Смольянов М. С. Юридическая процедура как гарантия прав человека: дисс. ... кандидата юридических наук. - Москва, 2011.- 198 с.

2. Henry M. Hart Jr. and Albert M. Sacks. Edited by William N. Eskridge, Jr. and Philip P. Frickey. New York: Foundation Press. 1994.

3. Николина К. Належна юридична процедура: теоретичні аспекти визначення. Вісник Київського національного університету імені Тараса Шевченка. Юридичні науки. 2012. Вип. 94. С. 44-46. Режим доступу: http://nbuv.gov.ua/UJRN/VKNU_Yur_2012_94_13.

4. Tyler, Tom R. and Hollander-Blumoff, Rebecca, «Procedural Justice and the Rule of Law: Fostering Legitimacy in Alternative Dispute Resolution» (2011). Faculty Scholarship Series. 4992. https://digitalcommons.law.yale.edu/fss_papers/4992

5. Weber, M. Economy and society. An outline of interpretive sociology. Edited By Guenther Roth and Claus Wittich. 3 Vols. New York: Bedminister Press, 1968. 1469 p.

DOI https://doi.org/10.30525/978-9934-588-92-1-13

\section{НАПРЯМИ ОПТИМІЗАЦІЇ ПРАВОВОЇ КОМУНІКАЦІЇ МГЖ ПРАВООХОРОННИМИ, ПРАВОЗАХИСНИМИ ТА СУДОВИМИ ОРГАНАМИ}

\author{
Погосян М. А. \\ адвокат, \\ аспірант кафедри історії і теорії держави та права \\ Запорізького національного університету \\ м. Запоріжжя, Україна
}

В умовах інформаційного суспільства правові відносини потребують модернізації форм взаємодії, однією 3 яких виступає правова комунікація. Сьогодні комунікативна взаємодія становить основу ефективних правових відносин між органами публічної влади та інститутами громадянського суспільства. 3 метою забезпечення динамічного розвитку правової системи України, грунтовного 
дослідження потребує механізм реалізації правової комунікації між правоохоронними, правозахисними та судовими органами, які становлять інституційну систему захисту прав i свобод людини $\mathrm{i}$ громадянина в Україні. Однак, між вищезазначеними органами сформовано комунікаційні бар'єри, які потребують пошуку дієвих методів подолання.

Питання пов'язані 3 налагодженням комунікації між правоохоронними, правозахисними та судовими органами досліджено у роботах вітчизняних та зарубіжних науковців, серед яких А. Антонов, Г. Атаманчук, С. Алексєєв, І. Бачила, М. Бойчук, М. Василик, І. Воронов, М. Гурицька, А. Колодій, В. Князєв, Р. Кирилюк, О. Корнієвський, М. Козюбра, В. Колісник, Л. Луц, О. Михайловська, Н. Нижник, В. Нікітін, А. Поляков, В. Погорілко, Г. Почепцов, П. Рабінович, П. Стецюк, А. Соколов, І. Ситар, Л. Сердюк, М. Слободяник, О. Скрипнюк, Н. Савінова, Ю. Тодика, А. Токарська, В. Федоренко, В. Цимбалюк, І. Честнов, В. Шаповал, І. Юрченко та інші.

Як слушно зауважує А. Токарська, вирішення проблемних відносин лежить у площині правової комунікації, яка є витоком формування та об'єктом застосування права. Право не може бути безапеляційною волею влади законодавчого суб'єкта або волею іншої держави; воно може розвиватися як онтологічний результат інтерсуб'єктивної взаємодії [1, с. 143].

Зважаючи на специфіку предмета взаємодії, форми правової комунікації потребують нестандартних рішень і творчих підходів із застосуванням спеціальних потоків та комунікаційних ресурсів, тобто із застосуванням інформаційних технологій.

Наголосимо, що сучасна правова комунікація формується під впливом глобалізаційних комунікативних процесів. О. Вдовіна підкреслює, що, бурхливий розвиток нових інформаційно-комунікаційних та Інтернет-технологій став передумовою для створення принципово нових моделей комунікації, розширення документальної комунікації за рахунок створення нових та вдосконалення наявних документопотоків, каналів та засобів комунікації, зокрема в інформаційно-комунікаційному просторі $[2$, с. 32]. Комунікаційна взаємодія, на думку Т. Бєльської, покращується при використанні інформаційних і комунікаційних технологій, що сприяє створенню інформаційно-відкритого глобального суспільства, розвитку інститутів демократії. Водночас існують певні обмеження i перешкоди до державних послуг в режимі повної інтерактивності, бо основна вимога режиму - це ідентифікація учасників взаємодії [3, с. 165]. 
Доцільно зазначити, що одним з визначальних критеріїв якості правової комунікації $\epsilon$ іiі ефективність, яка залежить від багатьох факторів. Формування ефективної системи правової комунікації, як зауважує Ю. Бистрова, $є$ не тільки довготривалим та складним соціальним процесом, спрямованим на правове регулювання, а й обміном, комплексним використанням соціально-правової значущої інформації та реалізацією на практиці соціально-правових дій [4, с. 33]. Результатом ефективної комунікації завжди є бажані зміни у свідомості чи поведінці отримувача інформації, які допомагають досягати поставлених перед організацією цілей. Колектив авторів Національної школи суддів зазначає, що ефективність комунікацій має проявлятися у підвищенні обізнаності щодо певної теми, підвищенні довіри до явища, формуванні певного іміджу в очах аудиторії, діях або утриманні від дій 3 боку отримувача інформації [5, с. 34]. Для підвищення ефективності комунікаційної взаємодії між правоохоронними, правозахисними та судовими органами, надзвичайно важливим $\epsilon$ нормативно-правове забезпечення механізму побудови дієвих комунікаційних каналів.

Сучасний стан організації комунікаційної взаємодії між правоохоронними, правозахисними та судовими органами не може бути визначений як високоорганізований та якісний. Серед факторів, які негативно впливають на ефективний розвиток комунікації у правових відносинах між вищевказаними органами можемо виділити наступні: нормативно-правова невизначеність чіткої стратегії побудови комунікаційних каналів зв'язку в межах взаємодії правоохоронних, правозахисних та судових органів; формальний підхід до провадження комунікаційної взаємодії, а також вибірковий підхід до надання інформації в межах взаємного діалогу та партнерства; відсутність контролю та нагляду за повнотою та достовірністю інформації, які надається суб'єктом комунікації під час відповідної взаємодії; незабезпеченість ефективних механізмів захисту інформації та комунікаційних каналів; незадовільна якість ресурсного забезпечення діяльності кожного суб'єкта комунікації та недостатній рівень кваліфікації і правової компетенції посадових та службових осіб правоохоронних, правозахисних та судових органів в умовах глобального інформаційного простору тощо.

О. Кучабського та О. Бажинової, які підкреслюють, що відсутність або неповнота змістових і правдивих об'єктних зворотних зв'язків не дає змоги визначати раціональність та ефективність організації i діяльності суб'єкта державного управління та виробляти заходи з їх підвищення [6, с. 197]. У контексті правової комунікативної взаємодії правоохоронних, правозахисних та судових органів, відсутність або 
неповнота наданих іншому суб'єкту даних може вплинути не тільки на ефективність комунікації між зазначеними органами, а й на ефективність захисту прав і свобод людини і громадянина.

Найбільш впливовим деструктивним елементом розвитку комунікаційної взаємодії $\epsilon$ недостатня нормативна врегульованість питання. Перші спроби подолання зазначеної прогалини здійснені у діяльності судових органів. О. Макеєва під комунікативною стратегією суду пропонує розуміти стратегічне планування 3 використанням комунікацій, залученням ресурсів та чіткими часовими межами, що полягає в налагодженні діалогу між судовою владою, іiі органами, громадськістю та ЗМІ, а також усередині самої судової системи, у створенні довірливих відносин з усіма зацікавленими сторонами [7, с. 65].

Необхідність запровадження комунікативної стратегії сьогодні здійснено й правоохоронними органами. Так, І. Козьяков наголошує, що загальна соціальна мета комунікаційної стратегії полягає у налагодженні діалогу між органами прокуратури, громадськістю та засобами масової інформації. Автор доходить висновку, що стратегічна комунікація нерозривно пов'язана 3 управлінськими процесами: планування, регулювання, контролю; іiі успіх залежить не лише від ефективності комунікації, але й від ефективності основної діяльності організації $[8$, с. 55]. Мета комунікаційної стратегії правоохоронних та судових органів спрямована на налагодження комунікації та підвищення довіри з боку інститутів громадянського суспільства.

Нормативно-правові акти які наразі регулюють питання пов'язані 3 правовою комунікацією між правоохоронними, правозахисними та судовими органами спрямовані в першу чергу на побудову ефективної комунікації між зазначеними органами під час взаємодії з інститутами громадянського суспільства. Розроблення спеціального акта щодо комунікативної взаємодії та налагодження комунікаційних каналів між органами, які здійснюють захист прав та свобод людини і громадянина матиме наслідком якісне оновлення та динамічний розвиток системи взаємних правових відносин між зазначеними органами.

Отже, у сучасному глобальному інформаційному суспільстві особливої актуальності набуває комунікація під час правової взаємодії між правоохоронними, правозахисними та судовими органами, оскільки вона спрямована на захист прав i свобод людини i громадянина. Сучасний стан реалізації правової комунікації між зазначеними органами не може бути визначений як достатньо ефективний, оскільки містить низку проблемних питань, які потребують грунтовного дослідження. Оптимізація правової комунікації між правоохоронними, правозахисними та судовими органами потребує розв'язання таких 64 
проблем, як нормативна неврегульованість комунікативних правових відносин між зазначеними суб'єктами; формальний та вибірковий підхід до надання інформації у межах взаємного співробітництва; невизначеність форм правової комунікації та незадовільна якість ресурсного забезпечення діяльності кожного суб'єкта комунікації у межах глобальної інформаційної взаємодії тощо.

\section{Література:}

1. Токарська А. Комунікативні напрями розвитку раціональності як складова національної безпеки. Вісник Національного університету «Львівська політехніка». Юридичні науки. 2017. № 865. С. 142-146.

2. Вдовіна О.О. Електронне діловодство як комунікаційна складова судочинства в Україні: дис. ... канд. наук із соціал. комунікац.: спец. 27.00.02. Харків; Київ, 2018. 206 с.

3. Бєльська Т.В. Комунікаційна взаємодія влади та громадськості в інформаційному суспільстві. Публічне управління: теорія та практика. 2012. C. $163-169$.

4. Бистрова Ю. В. Сучасні проблеми соціально-правової комунікації через призму викликів часу. Право та інноваційне суспільство. 2016. № 1. C. 33-39.

5. Логунова М.М., Лашкіна М.Г., Гвоздик П.О., Алєксєєв А.Г. Комунікації судової влади: науково-практичний посібник. Київ : АДЕФ-Україна, 2011. 276 с.

6. Кучабський О., Бажинова О. Механізми комунікації влади та громадськості в умовах глобалізації. Публічне управління: теорія та практика. 2012. № 4 (12). С. 196-201.

7. Макеєва О.М. Теоретико-правові засади правової комунікації судової влади. Юридичний вісник. 2019. № 4 (53). С. 62-68.

8. Козьяков I. Концептуальні основи комунікативної стратегії органів прокуратури. Юридична Україна. 2016. № 9-10. С. 51-57. 